\title{
8-bromo-5-hydroxy-7-methoxychrysin targeting for inhibition of the properties of liver cancer stem cells by modulation of Twist signaling
}

\author{
KAI-QUN REN ${ }^{1 *}$, XIAO-ZHENG CAO ${ }^{1 *}$, ZHI-HONG LIU $^{2}$, HUI GUO $^{2}$, MEI-FANG QUAN ${ }^{1}$, \\ FEI LIU ${ }^{1}$, LING JIANG ${ }^{1}$, HONG-LIN XIANG ${ }^{1}$, XI-YUN DENG $^{1}$ and JIAN-GUO CAO ${ }^{1}$ \\ ${ }^{1}$ Medical College, Hunan Normal University; ${ }^{2}$ Department of Pathology, \\ Hunan Provincial Tumor Hospital, Changsha, Hunan 410013, P.R. China
}

Received June 19, 2013; Accepted July 28, 2013

DOI: $10.3892 /$ ijo.2013.2071

\begin{abstract}
Emerging evidence has suggested that cancer stem cells with expression of surface biomarkers including CD133 and CD44 have more aggressive biological behavior, including epithelial-mesenchymal transition (EMT), which are closely related to invasion. The upregulation and nuclear relocation of the EMT regulator Twistl have been implicated in the tumor invasion and metastasis of human hepatocellular carcinoma (HCC). In this study, we aimed to isolate and characterize a small population of $\mathrm{CD} 133^{+}$cells that existed in the $\mathrm{HCC}$ cell line SMMC-7721 by MACS and investigated the possible roles of 8-bromo-7-methoxychrysin (BrMC), a synthetic analogue of chrysin, in inhibiting the properties of $\mathrm{CD}_{133}{ }^{+}$sphere-forming cells (SFCs) derived from the HCC cell line SMMC-7721, namely liver cancer stem cells (LCSCs). Based on the data, BrMC inhibited the proliferation, self-renewal and invasion of LCSCs in vitro and in vivo, downregulated the expression of the LCSC biomarkers CD133 and CD44 and induced EMT by downregulating the expression of Twist and $\beta$-catenin in LCSCs. BrMC potentiated the inhibition of LCSCs selfrenewal after reduction of twist protein levels, which was attenuated when twist was overexpressed. This study not only provides an important experimental and theoretical basis for investigation of BrMC in LCSCs, but also helps in the development of effective therapeutic medicine for HCC.
\end{abstract}

\section{Introduction}

Hepatocellular carcinoma (HCC) is the fifth most common solid tumor worldwide and the third most common cause of cancer-related death (1), resulting in almost 700,000 deaths in

Correspondence to: Professor Jian-Guo Cao, Medical College, Hunan Normal University, Changsha, Hunan 410013, P.R. China E-mail: caojianguo2005@126.com

${ }^{*}$ Contributed equally

Key words: hepatocellular carcinoma, cancer stem cell, 8-bromo-7methoxychrysin, Twist, epithelial-mesenchymal transition, $\beta$-catenin
2008. Clinically, HCC is often diagnosed at the late stage and medical treatments including chemotherapy, chemoembolization, ablation and proton beam therapy remain disappointing. There is an urgent need for new therapies for this aggressive disease. Recently, HCC progression has been thought to be driven by a small subset of cells, namely liver cancer stem cells (LCSC), through their capacity for self-renewal, production of heterogeneous progeny, resistance to chemotherapy and limitless proliferation. Many research groups in leukemia and several solid tumors supported the existence of such a subpopulation, which was successfully isolated and manifested marked tumorigenic capacity assessed by NOD/SCID mouse xenograft assay (2-8).

CD133 (AC133) is a highly conserved antigen as the human homologue of mouse Prominin-1, which was originally identified as a 5-transmembrane cell surface glycoprotein expressed in a subpopulation of the CD34 hematopoietic stem and progenitor cells derived from human fetal liver and bone marrow $(9,10)$. Notably, CD133 was expressed in most types of cancer stem cells within colon, breast, prostate, glioblastoma, medulloblastoma (MB) (11), and hepatocellular carcinoma $(12,13)$. In the past few years, compelling evidence has emerged in support of the notion that CD133 is a surface marker for LCSCs in human liver cancer cell lines and clinical samples and that $\mathrm{CD} 133^{+} \mathrm{LCSC}$ are associated with a hypoxic marker in clinical HCC samples, suggesting that CD133+ LCSCs have a critical role in tumor growth and resistance to anticancer therapy in liver cancers (14). CD44 is also regarded as an important marker for LCSC (15). In all HCC cell lines studied, CD133-positive cells showed higher cell migration activity and upregulated invasion- and EMT-associated genes including Twist (16).

The Twistl gene encodes a transcription factor containing a basic helix-loop-helix (bHLH) domain (17) and an aminoacid motif present in a protein family involved in the regulation of organogenesis (18-20). Recently, a number of studies have revealed that Twist plays essential roles not only in the development of multiple organs and systems, but also in cancer metastasis (21-23). It has been reported that Twist1 overexpression correlates positively with HCC metastasis (24). Further study on different HCC cell lines revealed that 
HCC cells with higher levels of Twist1 have higher metastatic ability. This suggests that Twist1 induces EMT changes, which are partially responsible for the increased HCC cell invasiveness (24). $\beta$-catenin, encoded by the CTNNB1 gene, has multiple functions, including mediation of cell adhesion and signal transduction. It combines with a variety of proteins to regulate cell proliferation and differentiation, which is critical for embryonic development and tumorigenesis. In addition, $\beta$-catenin has been shown to be accumulated within $67 \%$ of $\mathrm{HCC}$ tissues and is closely related to the clinicopathological features of HCC (25-27).

8-bromo-7-methoxychrysin (BrMC) is a novel synthetic analogue of chrysin (5,7-dihydroxyflavone, $\mathrm{ChR}$ ), which is a natural and biologically active flavone extracted from many plants, honey and bee propolis and has been shown to inhibit cell proliferation and induce apoptotic cell death in a variety of cancer cells (28-34). Because of the poor oral bioavailability, chrysin may not be successful when used as a dietary flavonoid for cancer chemotherapeutics (35). It has been reported that ChR halogenated derivatives had stronger bioactivities than the lead compound (36). Our previous study showed that the effect of BrMC on the inhibition of proliferation and induction of apoptosis in the colon cancer cell line HT-29 and the gastric cancer cell line SGC-7901, was stronger than that of ChR (37,38). BrMC also induces apoptosis of HCC cells by ROS generation and sustained JNK activation (39). Recently, our laboratory reported that BrMC affected the number of glioma stem-like cells (GSLCs) derived tumor spheres by MTT assay (40).

In this study, we investigated the possible functions of BrMC in inhibiting the characteristics of $\mathrm{CD}_{133^{+}}$sphereforming cells (SFC) derived from SMMC-7721 cell line in vitro and in vivo and explored the potential mechanisms.

\section{Materials and methods}

Cell culture and reagents. The hepatoma cell line SMMC-7721 and the immortalized embryo liver cell line L-02 were obtained from the Chinese Academy of Sciences (Shanghai, China). SMMC-7721 cells were maintained in Dulbecco's modified Eagle's medium (DMEM) supplemented with $10 \%$ fetal bovine serum, $100 \mathrm{U} / \mathrm{ml}$ penicillin and $100 \mu \mathrm{g} / \mathrm{ml}$ streptomycin (Invitrogen Life Technologies) in an incubator containing $5 \% \mathrm{CO}_{2}$ at $37^{\circ} \mathrm{C}$. BrMC was synthesized as described previously (37). Methyl thiazolyl tetrazolium (MTT) was purchased from Sigma (St. Louis, MO, USA). Fetal bovine serum was purchased from Hyclone (Thermo Scientific, USA). Trypsin and dimethyl sulfoxide (DMSO) were from Amersco Co. (USA).

Immunomagnetic separation of CD133 hepatoma cells. Cells were suspended with PBE incubation solution $(0.5 \%$ bovine serum albumin, $0.08 \%$ EDTA in PBS, $\mathrm{pH}$ 7.2) to a final concentration of $1 \times 10^{8}$ cells in $0.5 \mathrm{ml}$, then incubated with anti-CD133 antibody (final concentration $20 \mu \mathrm{g} / \mathrm{ml}$ ) at $4^{\circ} \mathrm{C}$ for $30 \mathrm{~min}$ and incubated with antibody-coated superfine magnetic beads (Miltenyi Biotec $\mathrm{GmbH}$, Bergisch Gladbach, Germany) at $10^{\circ} \mathrm{C}$ for $15 \mathrm{~min}$ and suspended in 20 times the total volume of PBE solution. The separation column was installed into a magnetic field and pretreated with $0.5 \mathrm{ml}$ PBE which was naturally eluted due to gravity. The incubated cell suspension was added to the separation column and naturally eluted. The column was rinsed twice and then separated from the magnetic field and subsequently inserted into a new tube, followed by administration of 1-2 $\mathrm{ml}$ PBE along the needle core to remove the CD133-positive cells. Simultaneously, negative cells were collected and the two types of cells were rinsed with medium.

Flow cytometry (FCM). The freshly isolated cells from each fraction were prepared at a concentration of $10^{5}$ cells/ ml using William's E medium (containing 20\% FBS) and incubated for 15-30 min at room temperature to block nonspecific sites. These cells were then washed twice with PBS and re-suspended in $990 \mu \mathrm{l}$ PBS. Subsequently, $10 \mu \mathrm{l}$ of antibodies, including CD133 (PE-conjugated, Biolegend, USA) and isotype control IgG2b (PE-conjugated, Biolegend), were added to each cell suspension. After $30 \mathrm{~min}$ of incubation at $4^{\circ} \mathrm{C}$ in the dark, the cells were washed twice with PBS, fixed in $0.1 \%$ formaldehyde and analyzed using the FACS Calibur ${ }^{\mathrm{TM}}$ system (BD Immunocytometry Systems, San Jose, CA, USA).

Spheroidformation and self-renewal assay. Parental cells were plated at a density of 2,000 cells/well in low adherence plates (6 wells) with serum-free stem cell conditional medium that containing DMEM/F12 (Gibco Invitrogen) plus $20 \mathrm{ng} / \mathrm{ml}$ EGF (Peprotech, NJ, USA), 10 ng/ml bFGF (Peprotech), 1X B27 (Invitrogen, CA, USA) and $0.4 \mu \mathrm{g} / \mathrm{ml}$ insulin (Peprotech). After 4 days of culture, sphere forming cells (SFCs) were visualized in a microscope and the number of cells after trypsin-EDTA digestion was counted.

To investigate self-renewal capacity of liver cancer sphere, single cell suspension prepared from the SFCs was diluted to 500 cells $/ \mathrm{ml}$. Single cell suspension $(2 \mu \mathrm{l})$ was plated in 96-well ultra-low plates containing $150 \mu \mathrm{l}$ serum-free medium per well. Wells containing about one or two cells were included and those with single cells were marked and monitored daily under a microscope (Nikon Eclipse TE2000-S) for 6 days. Then, the colonies were counted.

To analyze the effects of BrMC on self-renewal of SFCs, single cell suspension of SFCs was plated at a density of 2,000 cells/well in 6-well ultra-low plates. In addition, different concentrations of $\operatorname{BrMC}(0.1,0.3$ and $1.0 \mu \mathrm{M})$ were added to medium. After culturing for 6 days, the colonies were counted under a microscope.

Cell viability assay. Cell growth was measured by the MTT assay (Sigma). Briefly, SMMC-7721 cells were plated at a density of $5 \times 10^{3}$ cells/well in 96-well plates and allowed to attach for $24 \mathrm{~h}$ for each conditions, resulting in log phase growth at the time of drug treatment. BrMC $(0.1,0.3,1.0$ and $3.0 \mu \mathrm{mol} / \mathrm{l}$ ) was added to the wells for $48 \mathrm{~h}$. After treatment, MTT reagent was added to each well at $5 \mathrm{mg} / \mathrm{ml}$ in a $20-\mu 1$ volume and the reaction was incubated for another $4 \mathrm{~h}$. The formazan crystals formed by viable cells were subsequently solubilized in DMSO. Absorbance was measured at $550 \mathrm{~nm}$ using an automated microplate reader (Bio-Rad 550). Cell viability was expressed as a percentage of the value for control cultures. The cytotoxic effects of BrMC on SMMC-7721 sorted or non-sorted cells were expressed as $\mathrm{IC}_{50}$ values (the 
drug concentration that reduced the absorbance of treated cells by $50 \%$ compared to untreated cells), which was plotted using Graph Pad Prism 5 (GraphPad Software, San Diego, CA, USA). All experiments were carried out in triplicate.

Matrigel invasion assay. The invasion chamber has 24 cell culture inserts, each of which contains a polyethylene terepthalate membrane with $8-\mu \mathrm{m}$ pores (Corning Inc., Lowell, MA, USA) coated with Matrigel. Serum-free DMEM (1 ml) was added to the apical side of an insert and then $1 \mathrm{ml}$ of DMEM plus $10 \%$ fetal calf serum was added to the basal side of the insert as the chemoattractant. A total of 2,000 sorted or nonsorted SMMC-7721 cells were plated in the top chamber of the transwell and treated with $\operatorname{BrMC}(0.1,0.3,1.0$ and $3.0 \mu \mathrm{mol} / \mathrm{l})$ for $24 \mathrm{~h}$. The cells that had not invaded through the pores of the insert were scraped off the apical side of the inserts with a sterile cotton swab and discarded. Cells invaded to the lower chamber were fixed with methanol, stained with crystal violet and counted.

Experimental studies by a xenograft model in nude mice. Eightweek-old BALB/c mice of either sex were purchased from Hunan Agricultural University [SCXK (Xiang 2002-003)], maintained in Hunan Research Center for Safety Evaluation of Drug (Experimental Animal Center of Hunan Province) and then bred under specific pathogen-free conditions. Mice were kept in ventilated and filtered cages, fed an irradiated diet and housed on irradiated bedding. Food and water were supplied ad libitum. All animal experiments were performed in compliance with the guidelines of the Chinese government approved by the College BioResources Ethics Review Board. The area between the right leg and abdominal cavity in the nude mice was disinfected with iodine and a single cell suspension was injected into the mice subcutaneously using a $100-\mu 1$ micro syringe. The needle was held in place for $1 \mathrm{~min}$ and then gradually withdrawn to prevent liquid return. After inoculation, mice were housed in a sterile barrier system at constant temperature $\left(25 \pm 2^{\circ} \mathrm{C}\right)$ and humidity (45-50\%). Tumor formation and growth were observed daily. At the end of the experiment, the nude mice were sacrificed and the tumors were peered and fixed in fresh $4 \%$ paraformaldehyde, then embedded and H\&E stained.

RNA interference and pcDNA3-Twistl transfection. Twist1 siRNA (5'-GAU GGC AAG CUG CAG CUA UTT-3', 5'-AUA GCU GCA GCU UGC CAU CTT-3') and a non-silencing control siRNA (5'-UUC UCC GAA CGU GUC ACG UTT-3', 5'-ACG UGA CAC GUU CGG AGA ATT-3') were synthesized by GenePharma (Shanghai, China). SiRNA transfections were performed according to the manufacturer's instructions. Briefly, Twistl siRNA or negative control siRNA of $100 \mathrm{pmol}$ was diluted in $250 \mu \mathrm{l}$ of Opti-MEM I medium. Next, $5 \mu \mathrm{l}$ Lipofectamine 2000 was diluted in $250 \mu \mathrm{l}$ of Opti-MEM I Medium. After 5-min incubation, the diluted siRNA was mixed with diluted Lipofectamine 2000 gently and incubated for $20 \mathrm{~min}$ at room temperature. The oligomer-lipofectamine complexes were applied to the subconfluent cells which were seeded in a 6 -well plate $24 \mathrm{~h}$ before the experiment. Forty-eight hours after transfection, the Twist1 protein levels were assessed by western blotting.
Table I. Comparison of sphere-forming ability between CD133 cells and parental cells.

\begin{tabular}{lccccc}
\hline & \multicolumn{2}{c}{$\begin{array}{c}\text { No. of spheres } \\
\text { per 2,000 cells }\end{array}$} & & \multicolumn{2}{c}{$\begin{array}{c}\text { Sphere volume } \\
\left(\mu \mathrm{m}^{3}\right)\end{array}$} \\
\cline { 2 - 3 } \cline { 5 - 6 } Cell line & $\begin{array}{c}\text { Parental } \\
\text { cells }\end{array}$ & $\begin{array}{c}\mathrm{CD}^{3} 33^{+} \\
\text {cells }\end{array}$ & & $\begin{array}{c}\text { Parental } \\
\text { cells }\end{array}$ & $\begin{array}{c}\mathrm{CD}^{2} 133^{+} \\
\text {cells }\end{array}$ \\
\hline SMMC-7721 & $83 \pm 21$ & $232 \pm 45^{\mathrm{a}}$ & & $314 \pm 34$ & $986 \pm 52^{\mathrm{a}}$ \\
\hline
\end{tabular}

${ }^{\mathrm{a}} \mathrm{P}<0.05$ vs parental cells.

pcDNA3-Twist1 was purchased from GenePharma. To generate Twist1-expressing stable transfectants, L-02 and SMMC-7721 cells and SFCs of SMMC-7721 cell line were transfected with pcDNA3-Twist1 and stable clones were selected with $1000 \mu \mathrm{g} / \mathrm{ml}$ of G418 (Calbiochem) for 4 weeks.

Western blotting. Cells were washed once in pre-cold PBS and lysed in RIPA buffer [50 mM Tris- $\mathrm{HCl}$ (pH 7.2), $150 \mathrm{mM}$ $\mathrm{NaCl}, 1 \%(\mathrm{v} / \mathrm{v})$ Triton X-100, 1\% (w/v) sodium deoxycholate, $0.1 \%(\mathrm{w} / \mathrm{v})$ SDS and protease inhibitors]. Sample proteins were separated by $10 \%$ SDS-PAGE gel, after electrophoresis, proteins were transferred to PVDF (polyvinylidene difluoride) membrane (Bio-Rad, Richmond, CA, USA) at $4^{\circ} \mathrm{C}$ for $2 \mathrm{~h}$ at $100 \mathrm{~mA}$. The membranes were detected by rabbit polyclonal antibodies against ZO-1 (Abcam), Twist (Cell Signaling) or mouse monoclonal antibodies against $\mathrm{N}$-cadherin (Upstate), Vimentin Ab-2 (Neo Markers), E-cadherin (BD Transduction), $\beta$-catenin (Cell Signaling), $\beta$-actin (Sigma), respectively.

Statistical analysis. Data were presented as the mean \pm SD. Comparisons of experimental values between BrMC-treated cells and untreated controls were conducted using analysis of variance or the Kruskal-Wallis rank test. Statistical significance was defined as $\mathrm{P}<0.05$.

\section{Results}

LCSCs exist in hepatoma carcinoma cell line SMMC-7721 and in sorted $C D 133^{+}$cells. Human hepatoma carcinoma cell line SMMC-7721 was cultured in vitro as normal condition and the cells adhered to the culture slides (Fig. 1A, parental cells). In order to isolate LCSCs, SMMC-7721 cells were enzymatically dispersed into single-cell suspensions and subjected to immunostaining with an anti-CD133 antibody (Miltenyi Biotec Inc.) and FACS analysis. FACS results showed that the percentage of $\mathrm{CD}_{133}{ }^{+}$population was $\sim 58.72 \%$ (Fig. 1C), which is much higher than that of CD133- population $(1.07 \%)$ or non-sorted cells $(3.53 \%)$, indicating our immunomagnetic separation system is efficient. On the other hand, a major characteristic of CSC cells is their capacity to form threedimensional structures, or spheres. In the case of inoculation of 2,000 cells per well, there were many more spheres formed in the group of $\mathrm{CD}_{133^{+}}$cells (Fig. 1A and Table I), while at the same time-point of sphere formation, the sphere volume of $\mathrm{CD}_{133}{ }^{+}$cells was much greater than that of parental cells both for the first generation and for the second generation (Fig. 1A). 
A

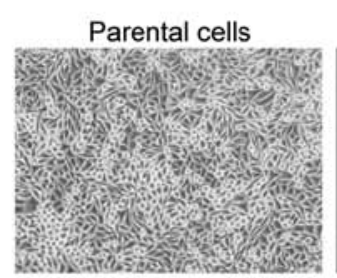

B

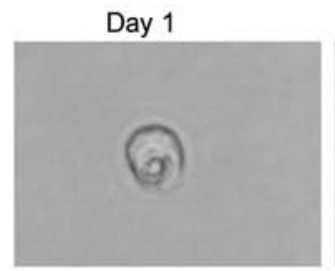

C
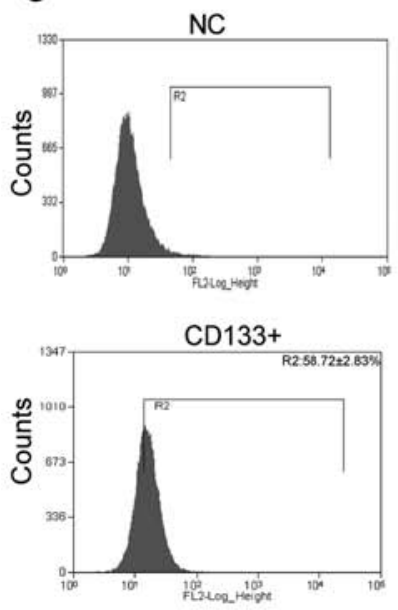

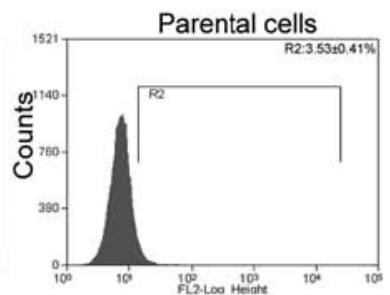

CD133-

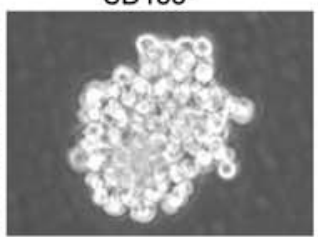

Day 3

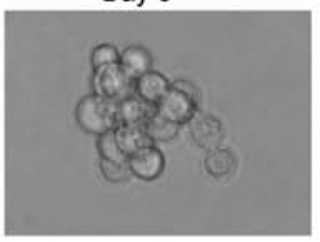

CD133-

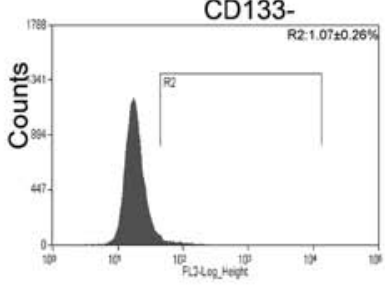

CD133+

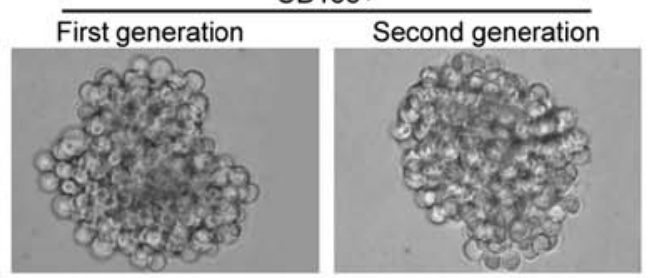

Day 6
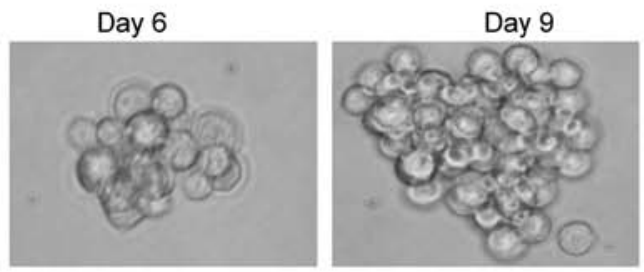

D

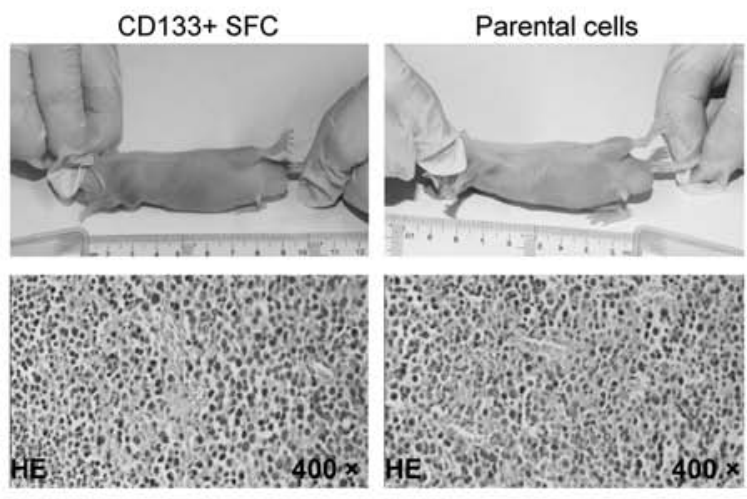

Figure 1. Identification of LCSCs in SMMC-7721 cell line. (A) Human hepatoma carcinoma cell line SMMC-7721 (parental cell) was cultured in DMEM medium. In conditional stem cell culture system, sphere-forming cells (SFCs) can be passaged and form spheres for the second generation and the volume and the size of CD133+ SFCs were much larger than that of parental cells. (B) The process of a single CD133 $3^{+}$SFCs of SMMC-7721 cell line to form a sphere was 1 , 3, 6 and 9 days, respectively. (C) FACS analysis was performed to check the CD133 expression rates. (D) CD133 ${ }^{+}$SFCs (1x104) derived from SMMC-7721 cell line, or $1 \times 10^{5}$ parental cells were subcutaneous seeded into male Balb/c-nu mice. Six weeks later, there were visible tumors in CD133 ${ }^{+}$SFCs xenotransplantation and no tumor seen in parental cells xenotransplantation. H\&E staining revealed that the histological features of xenograft tumors in the CD133 ${ }^{+} \mathrm{SFCs}$ were similar to those in parental SMMC-7721 cells.

One of the cancer stem cell characteristics is self-renewal. To test this, one SMMC-7721 cell per well was plated to a 96-well plate and the wells with one cell were visualized daily. Fig. 1B shows the process of single SMMC-7721 cell forming a sphere. The result showed that the SMMC-7721 derived $\mathrm{CD} 133^{+}$cells have the ability to form spheres, even a single cell became a new hepatoma cancer sphere (Fig. 1B). These data indicate that the SMMC-7721 derived $\mathrm{CD}_{133^{+}}$cell population has the capacity of self-renewal.

Xenotransplantation is the gold standard for evaluating tumorigenicity of tumor cells. We tested whether our sorted CD133 ${ }^{+}$LCSCs have more tumor initiating capability. We injected different cell numbers of sphere-formed SMMC-7721 CD133+ LCSCs, or parent cells into Balb/c-nu mice to get the minimum number of seeded cells in vivo tumorigenicity, respectively.

As shown in Table II and Fig. 1D, as few as 10,000 cells from the SMMC-7721 CD133 ${ }^{+}$SFC were able to grow into tumors $(4 / 4,100 \%)$ when subcutaneously injected into Blab/ c-nu mice, while $1 \times 10^{6}$ parental cells were needed for tumor
Table II. Xenotransplantation of human hepatoma carcinoma cell line SMMC-7721 and its LCSCs into Balb/c-nu immunodeficient mice.

\begin{tabular}{lccc}
\hline Cell & $\begin{array}{c}\text { Inoculum } \\
\text { size }\end{array}$ & $\begin{array}{c}\text { Tumor } \\
\text { incidence }^{\mathrm{a}}\end{array}$ & $\begin{array}{c}\text { Latency } \\
\text { period (days) }^{\mathrm{b}}\end{array}$ \\
\hline Parental cell & $1 \times 10^{4}$ & $0 / 4$ & - \\
& $1 \times 10^{5}$ & $1 / 4$ & 47 \\
& $1 \times 10^{6}$ & $4 / 4$ & 35 \\
$\mathrm{CD}^{2} 33^{+}$sphere & $2 \times 10^{3}$ & $3 / 4$ & 36 \\
cells & $1 \times 10^{4}$ & $4 / 4$ & 17 \\
& $1 \times 10^{5}$ & $4 / 4$ & 9 \\
\hline
\end{tabular}

${ }^{a}$ The number of tumors detected/number of injections. ${ }^{\mathrm{b}}$ Approximate number of days from tumor cell injection to appearance of a tumor.

formation $(4 / 4,100 \%)$. There was also a great difference in the time needed for tumor formation, $\sim 17$ days for $\mathrm{CD}_{133^{+}}$sphere 
A

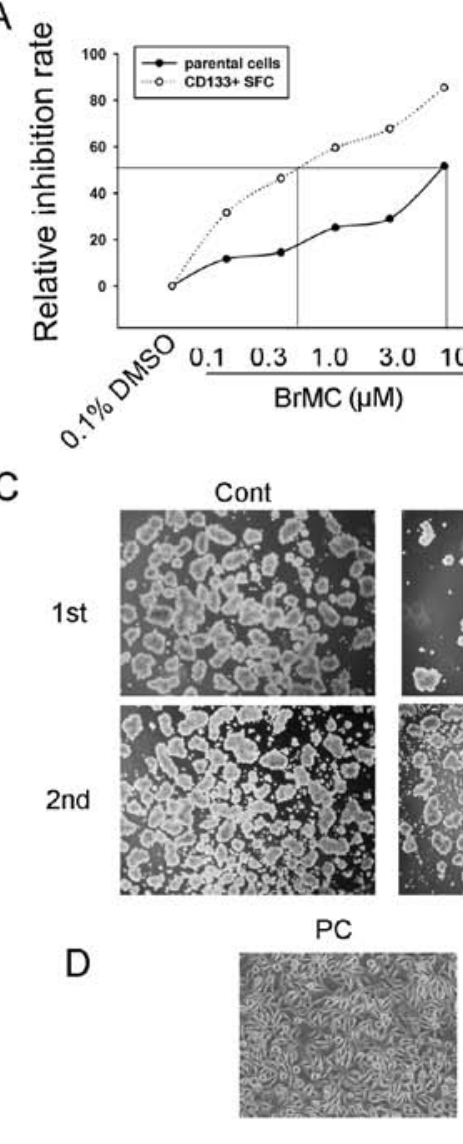

E

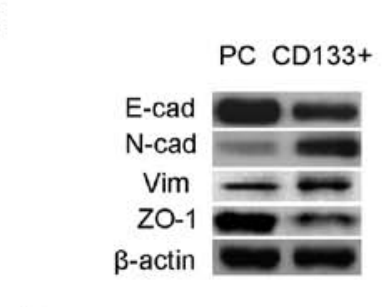

B

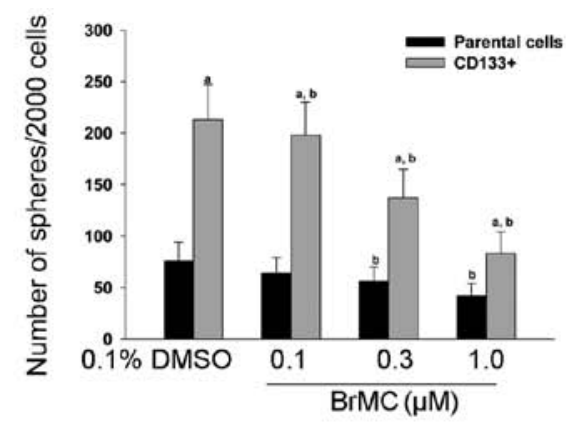

$\operatorname{BrMC}(\mu \mathrm{M})$

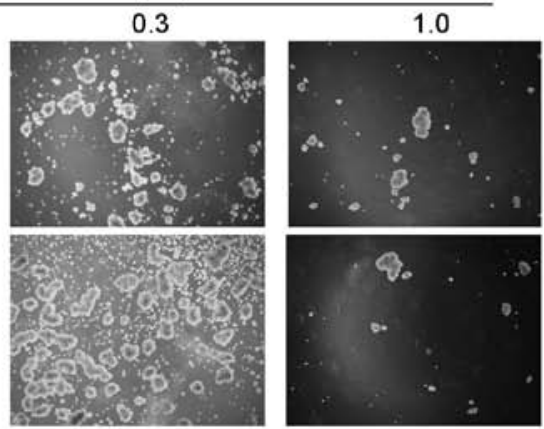

CD133+

CD133/0.1 $\mu \mathrm{M}$ BrMC
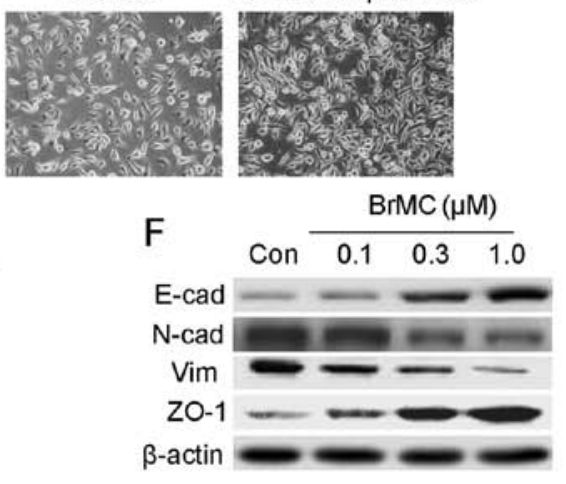

CD133+ ( $\mu \mathrm{M} \mathrm{BrMC})$

G

NC

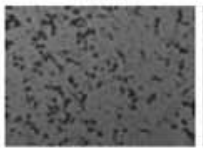

DMSO

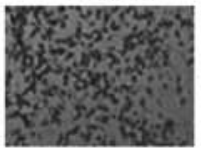

0.1

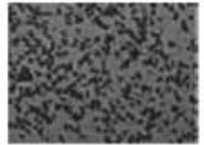

0.3

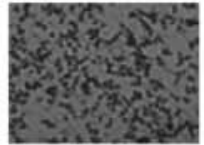
1.0

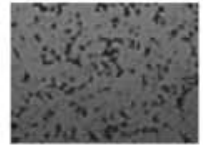

Figure 2. BrMC suppresses proliferation, self-renewal and invasion of LCSCs. (A) The relative inhibition rate (\%) of BrMC on CD133+ SFCs or parent cells (PC) was determined by MTT assay. The $\mathrm{IC}_{50}$ of $\mathrm{BrMC}$ to $\mathrm{CD} 133^{+} \mathrm{SFCs}$ was $0.5 \mu \mathrm{mol} / 1$, while the parental cells is $13.1 \mu \mathrm{mol} / 1$. (B) BrMC reduced the numbers of spheroids in a dose-dependent manner. ${ }^{\mathrm{a}} \mathrm{P}<0.05$ vs parental cells treated by $0.1 \%$ DMSO. ${ }^{\mathrm{b}} \mathrm{P}<0.05$ vs $\mathrm{CD} 133^{+}$treated by $0.1 \% \mathrm{DMSO}$. (C) BrMC reduced the size and number of spheroids in a dose-dependent manner either for the first generation of LCSCs or for the second generation. (D) BrMC induced mesenchymal to epithelial transformation. The $\mathrm{CD}_{133^{+}} \mathrm{SFCs}$ were grown in plates, treated with $0.1 \mu \mathrm{M}$ of BrMC, the cell morphology tended to be epithelial phenotype. (E) CD133+ SFCs highly express mesenchymal cell biomarker N-cadherin and Vimentin and express low levels of epithelial biomarkers E-cadherin and ZO-1. (F) BrMC decreased the expression of N-cadherin and Vimentin and increased the expression of E-cadherin and ZO-1 in CD133+ SFCs. (G) BrMC inhibited the invasion ability of CD133+ $3^{+}$FCs in a dose-dependent manner.

cells compared to $\sim 35$ days for the parental cells (Table II). These results demonstrate that $\mathrm{CD} 133^{+} \mathrm{SFCs}$ derived from SMMC-7721 cell line was highly tumorigenic and characteristic of CSC.

BrMC suppresses proliferation, self-renewal and invasion of LCSCs. Previously, our laboratory reported that the BrMC inhibits proliferation and induces apoptosis of HCC cells (39). Here, we performed MTT assay to analyze the influence of
BrMC to CD133 ${ }^{+}$SFCs that derived from the SMMC-7721 cell line. As shown in Fig. 2A, as compared to negative control (0.1\% DMSO), the $\mathrm{IC}_{50}$ of $\mathrm{BrMC}$ to $\mathrm{CD} 133^{+}$sphere cells is $0.5 \mu \mathrm{mol} / 1$, which is much lower than that of parental cells (13.1 $\mu \mathrm{mol} / \mathrm{l})$, suggesting that BrMC preferentially inhibits the proliferation of $\mathrm{CD}_{133^{+}}$sphere cells.

In order to observe whether BrMC efficiently inhibits the self-renewal of our sorted SMMC-7721 CD133+ sphere cells, we treated the spheres seeded in 6-well low adherence plates 
A

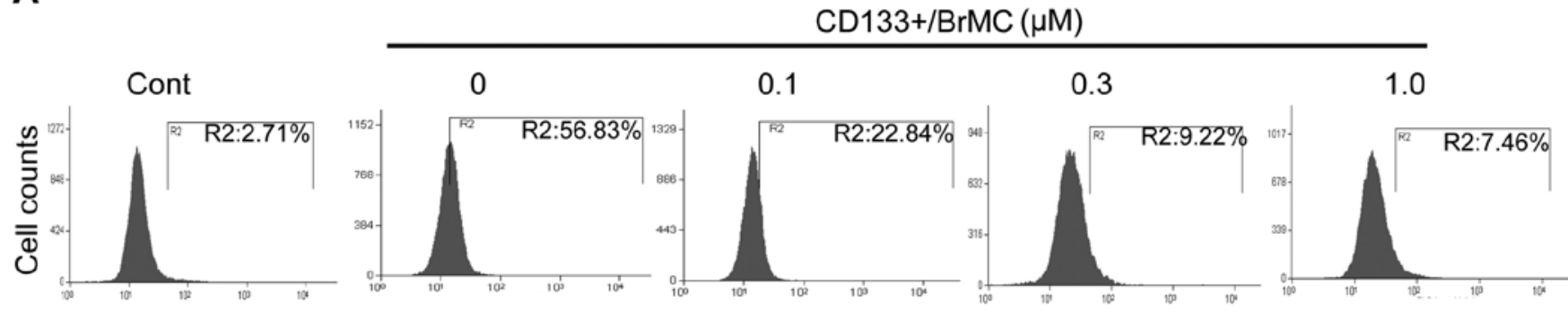

B

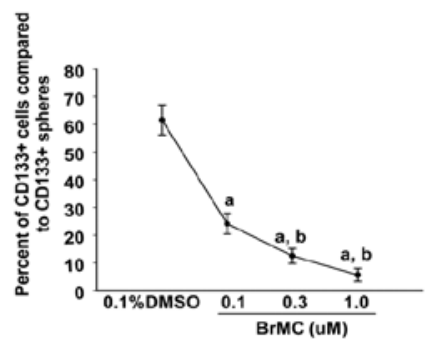

D

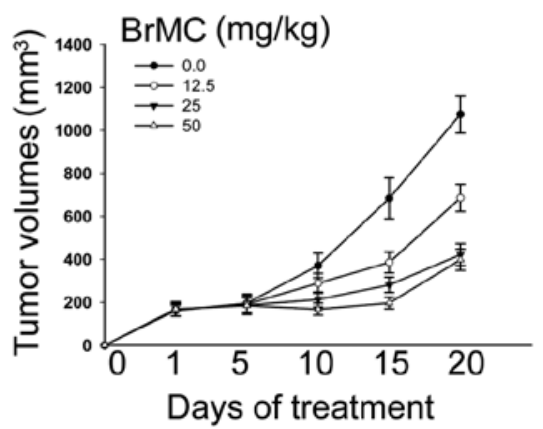

C

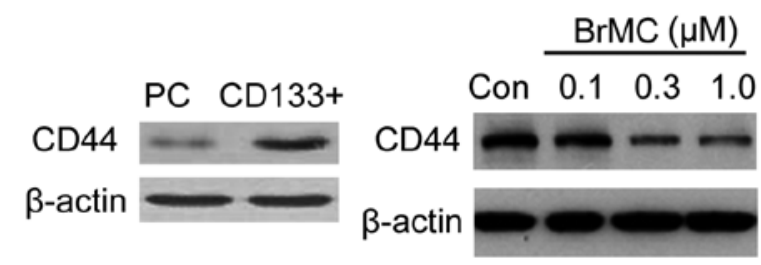

E
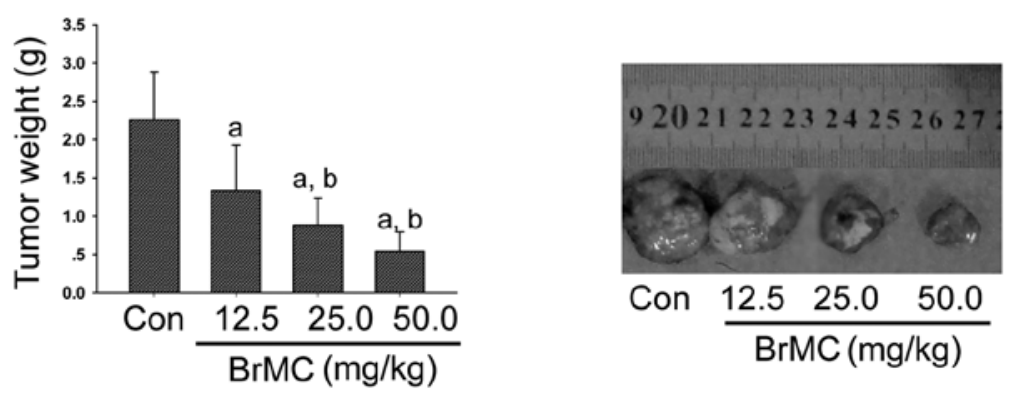

Figure 3. BrMC downregulates the expression of LCSC biomarkers CD133 and CD44. (A) FACS analysis results show the effects of BrMC on the expression of CD133 in CD133 ${ }^{+}$SFCs of SMMC-7721 cell line. (B) Statistical analysis of (A), each experiments were performed in triplicate and representative examples are shown ( ${ }^{\mathrm{a}} \mathrm{P}<0.01$ vs groups treated by $0.1 \%$ DMSO; ${ }^{\mathrm{P}}<0.05$ vs groups treated with $0.1 \mu \mathrm{M}$ of BrMC). (C) Western blot analysis show the effects of BrMC on expression of CD44. (D) BrMC suppressed tumor growth in vivo, while in CD133+ SFC xenograft nude mouse models, different concentrations of BrMC $(0,12.5,25$ and $50 \mathrm{mg} / \mathrm{kg})$ were daily lavaged for 20 days. (E) Representative images of tumors were taken.

with different concentrations of BrMC. Forty-eight hours after treatment, the spheres were passaged for second sphere formation without treatment, after 6-day culture, at which time-point, the second spheres were counted under a microscope. As depicted in Fig. 2B and C, BrMC inhibited both the size and the numbers of the first or second passaged spheres in a dose-dependent manner.

Epithelial-mesenchymal transition (EMT) is a critical process providing tumor cells with the ability to migrate and escape from the primary tumor and metastasize to distant sites. Recently, EMT has been shown to be associated with the cancer stem cell (CSC) phenotype in hepatoma cancer (2,41-43). Based on above mentioned results, we further examined whether BrMC affects the EMT process of CD133+ SFCs derived from the SMMC-7721 cell line. As shown in Fig. 2D, the parental cells exhibited epithelial cell morphology. When the SMMC-7721 cell line derived CD133 ${ }^{+}$sphere cells were cultured in $10 \%$ FBS and allowed to adhere to plates, the cells presented fusiform morphology, which is the mesenchymal cell phenotype. However, after treatment with $0.1 \mu \mathrm{M} \mathrm{BrMC}$, the cell morphology tended to change to epithelial phenotype.
The experiments showed that SMMC-7721-derived CD133+ sphere cells possess mesenchymal cell morphology and BrMC induced mesenchymal to epithelial transformation.

We also performed western blot analysis to check the variety of EMT biomarkers in CD133+ sphere cells, parental cells and the cell populations treated with the indicated concentration of BrMC $(0.1,0.3$ and $1.0 \mu \mathrm{M})$. From Fig. $2 \mathrm{C}-\mathrm{F}$ we can see that the $\mathrm{CD}_{133}{ }^{+}$sphere cells highly expressed mesenchymal cell biomarker $\mathrm{N}$-cadherin and Vimentin and epithelial biomarkers E-cadherin and ZO-1 at low levels. While the treatment of BrMC leads to downregulation of $\mathrm{N}$-cadherin and Vimentin and upregulation of E-cadherin and $\mathrm{ZO}-1$ in $\mathrm{CD}_{133^{+}}$sphere cells. Together, our data suggest that BrMC can effectively inhibit EMT in LCSCs.

We next performed a transwell assay to demonstrate whether BrMC affects invasion of LCSC. As described in Materials and methods, a total of 2,000 parental or CD133+ cells derived from SMMC-7721 cells were treated with BrMC $(0.1,0.3,1.0$ and $3.0 \mu \mathrm{mol} / \mathrm{l})$ for $24 \mathrm{~h}$ and then plated in the top chamber of the transwell, cells that invaded the lower chamber were counted. As shown in Fig. 2G, sorted CD133+ ${ }^{+}$sphere cells 
Table III. Effects of BrMC on the secondary tumor formation ability in BALB/c nu mice for SMMC-7721 derived CD133+ SFCs.

\begin{tabular}{cccccc}
\hline & \multicolumn{2}{c}{$\begin{array}{c}\text { Secondary tumor } \\
\text { incidence }\end{array}$} & & \multicolumn{2}{c}{$\begin{array}{c}\text { Secondary tumor } \\
\text { volumes }\left(\mathrm{mm}^{3}\right)\end{array}$} \\
\cline { 2 - 3 } \cline { 5 - 6 } Days & Con & BrMC & & Con & BrMC \\
\cline { 6 - 6 } 1 & $0 / 12$ & $0 / 12$ & & - & - \\
3 & $0 / 12$ & $0 / 12$ & & - & - \\
6 & $3 / 12$ & $0 / 12$ & & $19 \pm 2.7$ & - \\
12 & $8 / 12$ & $0 / 12$ & & $92 \pm 27.6$ & - \\
15 & $12 / 12$ & $1 / 12$ & & $258 \pm 89.1$ & 14 \\
18 & $12 / 12$ & $1 / 12$ & & $599 \pm 152$ & 18 \\
21 & $8 / 8$ & $1 / 8$ & & $394 \pm 64$ & 29 \\
24 & $8 / 8$ & $1 / 8$ & & $638 \pm 168$ & 37 \\
27 & $4 / 4$ & $0 / 4$ & & $227 \pm 82$ & - \\
30 & $4 / 4$ & $0 / 4$ & & $493 \pm 91$ & - \\
33 & $4 / 4$ & $0 / 4$ & $686 \pm 187$ & - \\
\hline
\end{tabular}

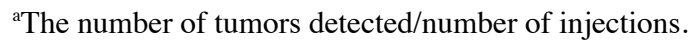

were statistically significantly more invasive than parental SMMC-7721 cells. BrMC inhibited the invasion of CD133+ sphere cells in a dose-dependent manner.

BrMC downregulates the expression of LCSC biomarkers $C D 133$ and CD44. In our study, we have shown that the $\mathrm{CD}_{133}{ }^{+}$sphere cells derived from SMMC-7721 cell line had the property of self-renewal, EMT and were highly tumorigenic. To better understand the influence of BrMC on the biomarkers of LCSCs, we performed FACS and western blotting to analyze the expression of CD133 and CD44. The results provided evidence that in $\mathrm{CD}_{133}{ }^{+}$sphere cells derived from SMMC-7721 cell line, BrMC downregulated the expression of CD133 (Fig. 3A and B) and CD44 in a dose-dependent manner (Fig. 3C).

BrMC suppresses tumor growth in vivo. To determine whether BrMC targeted the inhibition of growth of LCSCs in vivo, we transplanted human SMMC-7721-originated CD133+ ${ }^{+}$spheres subcutaneously to Balb/c-nu mice for a xenograft nude mouse model. Two weeks after transplantation, mice were randomized to four groups and received daily gavage of indicated different dosage of $\operatorname{BrMC}(0,12.5,25$ and $50 \mathrm{mg} / \mathrm{kg})$. After treatment of 20 days, the volume of tumors that were treated by high doses for 25 and $50 \mathrm{mg} / \mathrm{kg}$ reduced to half size of that of model controls (Fig. 3D). To further confirm this result, we dissected these tumors in mice and re-seeded them subcutaneously to different nude mice. In order to avoid the possible changes caused by heterogeneity, we seeded 50,000 tumor cells from the model control in the side of forelimb, seeded another 50,000 tumor cells from xenograft nude mice that were treated by high dose of BrMC $(50 \mathrm{mg} / \mathrm{kg})$ into the other side of forelimb. Interestingly, we can see from Table III, the tumor cells from the control group grew very fast and the final volume reached $567-686 \mathrm{~mm}^{3}$. However, the tumor cells originated from xenograft nude mice that were treated with BrMC did not grow until day 33 after transplantation. Among the 12 mice that received the BrMC treated tumor cells, only one mouse formed a small tumor $\left(37 \mathrm{~mm}^{3}\right)$. In the control group, however, as early as the sixth day of tumor cell injection, the tumors emerged and all tumors appeared on the 15 th day. These results suggest that BrMC is able to eliminate LCSCs in the initial transplanted tumors, thereby inhibiting tumor re-growth of the secondary inoculated mice, hinting that BrMC could eradicate LCSCs in vivo.

BrMC downregulates the expression of Twist and $\beta$-catenin in LCSCs. Transcription factor Twist and $\beta$-catenin were proved to be the critical epithelial-mesenchymal transitional molecules (44-47). In cancer cells, the nuclear translocation of CD44 causes stimulation of Twist transcription, which mediates the MSC-triggered epithelial-to-mesenchymal transition (EMT) of carcinoma cells (44). Based on the results that BrMC downregulates the expression of CD133 and CD44 and inhibits EMT in LCSCs, we further investigated the effects of BrMC on the expression of Twist and $\beta$-catenin, as reported by other groups $(45,48,49)$, Twist and $\beta$-catenin were highly expressed in our sorted CD133 ${ }^{+}$sphere cells (Fig. 4A). Western blot analysis indicated that the protein levels were downregulated after these $\mathrm{CD} 133^{+} \mathrm{SFCs}$ were treated by the indicated concentration of $\operatorname{BrMC}(0.1,0.3$ and $1.0 \mu \mathrm{M})$ (Fig. 4A).

Synergistic inhibition of self-renewal of LCSCs by BrMC and Twist silencing. To further explore the biological functions of Twist in $\mathrm{CD}_{133}{ }^{+} \mathrm{SFC}$ and the maintenance of LCSC characteristics, we silenced the expression of Twist by RNA interference in $\mathrm{CD}_{133^{+}}{ }^{\mathrm{SFC}} \mathrm{s}$ of the SMMC-7721 cells. The mRNA levels and protein expression of Twist decreased significantly after transfection with Twist siRNA (Fig. 4B). Interestingly, as the protein levels of Twist decreased, the $\beta$-catenin expression was reduced (Fig. 4B). Furthermore, the decreased expression of Twist also downregulated the sphere formation capacity of CD133+ SFCs of SMMC-7721 cell line (Fig. 4C and D). As BrMC inhibits proliferation and self-renewal of CD133 ${ }^{+}$ sphere-forming cells derived from the SMMC-7721 cell line, to confirm the results, we treated $\mathrm{CD} 133^{+}$SFCs of the SMMC7721 cells that were transfected with Twist siRNA with $0.1 \mu \mathrm{M}$ of BrMC again. Fig. 4E shows the cells that were transfected with Twist siRNA, the addition of BrMC further decreased the protein levels of Twist and the sphere-forming capacity in this group also reduced more by the co-treatment with Twist siRNA and $0.1 \mu \mathrm{M}$ of BrMC (Fig. 4F and G), indicating synergistic inhibition of self-renewal of LCSCs.

Overexpression of Twist attenuates inhibition of LCSC selfrenewal by BrMC. To corroborate whether Twist rescued BrMC, we transfected the plasmid pcDNA-Twist and negative control pcDNA3.1 to the human embryonic liver cell line L-02, HCC cell line SMMC-7721 and CD133 ${ }^{+}$sphere cells derived from SMMC-7721 cells, respectively. As shown in Fig. 5A, compared to negative control vector pcDNA3.1, the three cell lines significantly overexpressed Twist. Tumor sphere forming experiment showed that the ectopic expression of Twist in these cell lines promoted the tumor sphere 
A

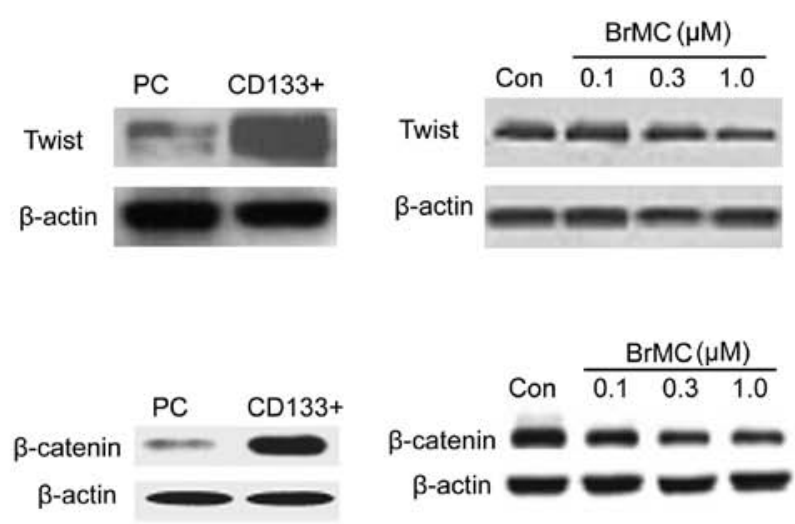

B
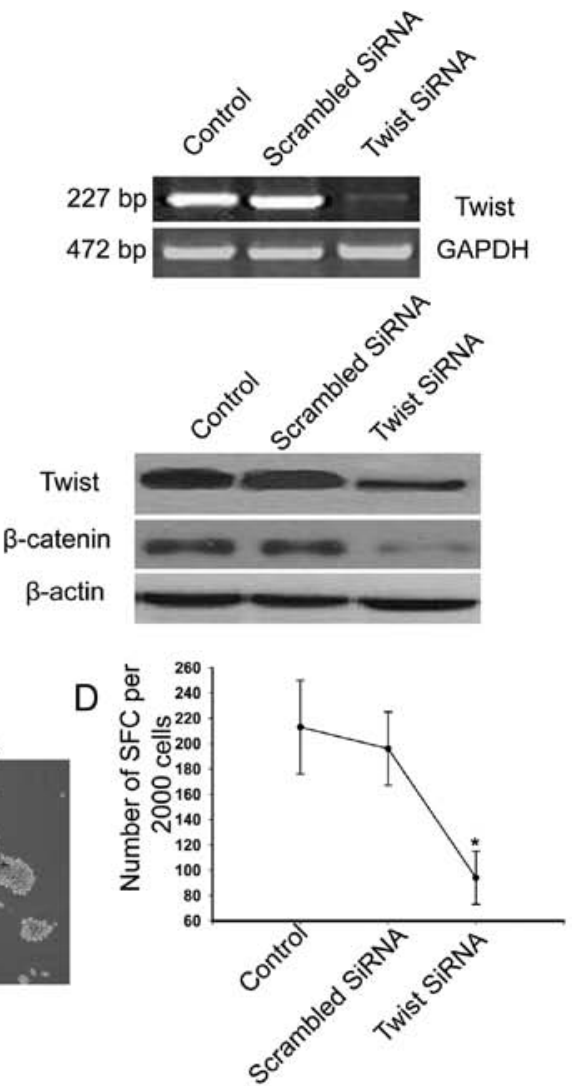

$\mathrm{F}$

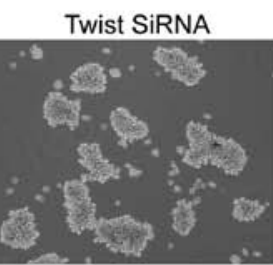

Control

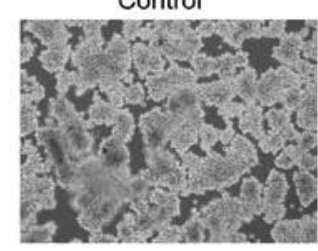

$\operatorname{BrMC}(0.1 \mu \mathrm{M})$

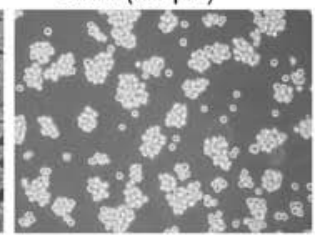

$\operatorname{BrMC}(0.1 \mu \mathrm{M})+$ Twist siRNA
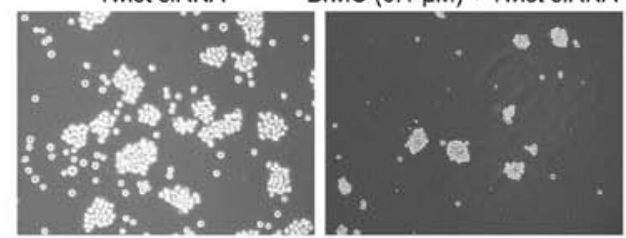

G

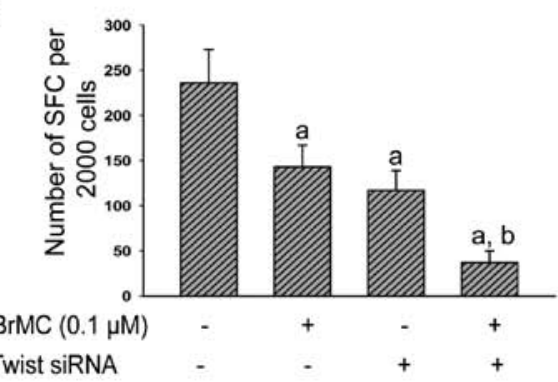

Figure 4. Synergistic inhibition of self-renewal of LCSCs by BrMC and Twist silencing. (A) Western blot analysis showed that Twist and $\beta$-catenin were highly expressed in CD133 ${ }^{+}$SFCs of SMMC-7721 cell line, BrMC downregulated the expression of Twist and $\beta$-catenin in a dose-dependent manner. (B) The mRNA levels and protein levels of Twist decreased significantly after transfection with Twist siRNA. (C) The downregulation of Twist decreased the sphere forming ability of CD133+ ${ }^{+}$SFCs of SMMC-7721 cell line. (D) Statistical analysis of (C), each experiment was performed in triplicate and representative examples are shown. (E) Western blot analysis revealed that the addition of BrMC further decreased the protein levels of Twist. (F) Synergistic inhibition of the sphere forming ability of CD133 ${ }^{+}$SFCs of SMMC-7721 cell line by BrMC and Twist silencing. (G) Statistical analysis of (F), each experiment was performed in triplicate and representative examples are shown.

formation (Fig. 5B and C). We also treated CD133+ SFCs of SMMC-7721 cells that were transfected with pcDNA-Twist followed by treatment with $0.1 \mu \mathrm{M}$ of BrMC. After addition of $\mathrm{BrMC}$, the number of spheres formed in this group was relatively more than that of the control groups (Fig. 5D). These results suggest that Twist overexpression could partly reduce the inhibitory effect of BrMC on self-renewal of LCSCs.

\section{Discussion}

Cancer stem cell research is becoming a growing and exciting field. In fact, it appears that most cancer types contain populations of cells that exhibit stem-cell properties. CSCs have the ability to renew indefinitely, which can drive tumor development and metastatic invasion. As these cells are classically resistant to conventional chemotherapy and to 
A

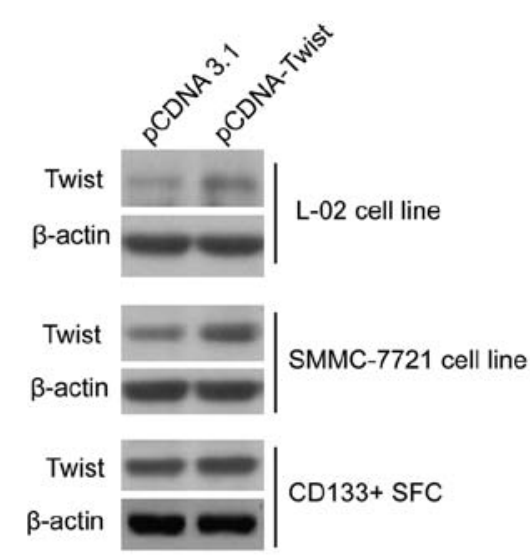

C

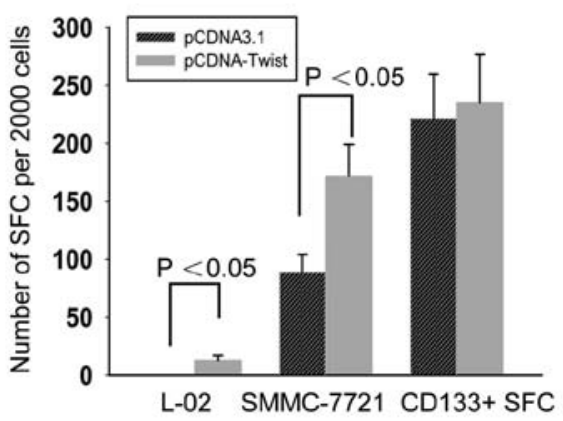

B
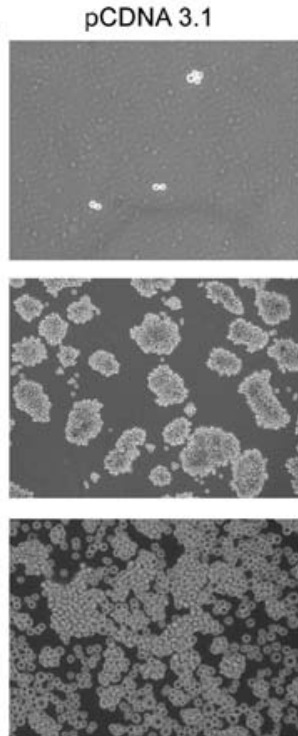

D
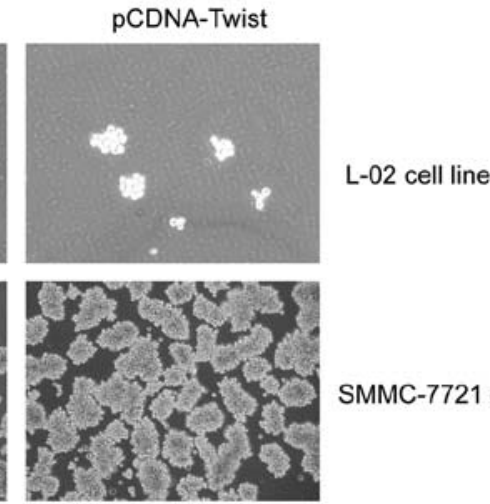

SMMC-7721 cell line

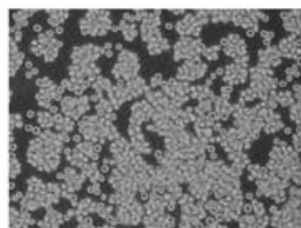

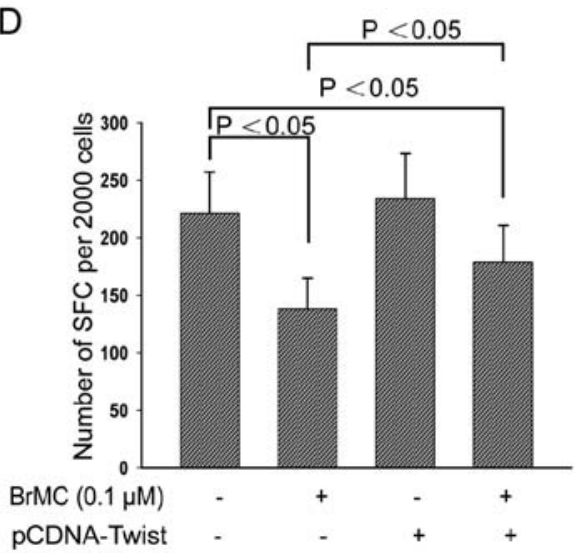

Figure 5. Overexpression of Twist attenuates the inhibitory effect of BrMC on LCSCs self-renewal. (A) Western blot analysis showed overexpression of Twist after transfection with plasmid pcDNA-Twist in L-02, SMMC-7721 cells and SFCs of SMMC-7721 cell line. (B) The ectopic expression of Twist in these cell lines promoted the tumor sphere formation. (C) Statistical analysis of (B), each experiment was performed in triplicate and representative examples are shown. (D) The sphere forming ability of CD133+ ${ }^{+}$SFCs derived from HCC SMMC-7721 cell line that was treated with BrMC was partly rescued after overexpression of Twist.

radiation therapy, they may contribute to treatment failure and relapse. Most cancer research experts focused on isolation and targeted killing of CSCs and the development of novel strategies for antitumor therapy relies on the use of biomarkers to identify, enrich and/or isolate the cell population(s) of interest. Magnetic activated cell sorting (MACS) is one of the specific methods to separate CSCs, which are based on cell surface markers. The proposed markers for liver CSCs include CD133, CD90, CD44, CD13, EpCAM and OV6, on the basis of the hypothesis that CSCs are originated from somatic stem cells and accordingly express the same surface markers $(50,51)$ Prominin-1 (CD133) is generally regarded as one of the most important molecular markers for stem cells, cancer stem and stem-like cells in tumors originating from colon cancer (52), glioblastoma multiforme (GBM) cell line (53), HCC $(12,54)$, pancreatic cancer (55), gastric cancer (56), and lung cancer (57) have been reported.

Although the cell surface expression of the human CD133 antigen, in particular of the AC133 epitope, is among those that have been most frequently studied in solid cancers, no mecha- nism has yet been proposed to link CD133 expression with the CSC phenotype (58). In our study, we quantified percentage of the isolated CD133+ cells from the SMMC-7721 cell line by flow cytometry. There was no detectable $\mathrm{CD} 133^{+}$cell in the CD133 population $(1.07 \%$ ), while the percentage of CD133+ population was $\sim 58.72 \%$, indicating that CD133 is highly expressed in LCSCs derived from SMMC-7721, which was in agreement with the study by Yin $e t a l$, who also performed flow cytometry, for purity, before and after MACS sorting from SMMC-7721 cell line and the $\mathrm{CD}_{133^{+}}$groups ranged from 60.2 to $91.2 \%$ compared to non-sorted SMMC-7721 cells $(0.1-2 \%)(3,59)$.

Sphere formation experiment indicates high levels of CD133 were associated with increased spheroid forming capacity both for the first passage and for the second passage in vitro. Next, the ability of tumorigenicity was measured in $\mathrm{BALB} / \mathrm{c}$ nu mice to verify $\mathrm{CD} 133^{+}$sphere cells derived from SMMC-7721 is LCSCs. As expected, CD133 ${ }^{+}$sphereforming cell population exhibited stronger tumorigenicity than others, even 10,000 cells were enough to form tumors, 
showing slight difference compared to results by De Hert et al (60), who used as few as 500 cells from the PLC/PRF/5 spheres to form a tumor when subcutaneously injected into NOD/SCID mice, while $2 \times 10^{5}$ parental cells were needed.

During EMT, epithelial cells lose their characteristics and gain mesenchymal features. It has been suggested that transformed epithelial cells can activate embryonic programs of epithelial plasticity and switch from a sessile, epithelial phenotype to a motile, mesenchymal phenotype. Induction of EMT can, therefore, lead to invasion of surrounding stroma, intravasation, dissemination and colonization of distant sites. According to the cancer stem cell hypothesis, sustained metastatic growth requires the dissemination of a CSC from the primary tumor followed by its re-establishment in a secondary site. SNAI, ZEB and TWIST family members repress the $\mathrm{CDH} 1$ gene to induce EMT, but also regulate the transcription of other target genes. TWIST1 is upregulated in human breast cancer, gastric cancer, esophageal cancer and prostate cancer (61). The activation of Twist caused translocation of $\beta$-catenin into the nucleus and elevated $\mathrm{Wnt} / \beta$-catenin signaling promotes EMT transition $(62,63)$. In this study, the knockdown of Twist leads to reduced $\beta$-catenin expression (Fig. 4B), hinting that $\beta$-catenin is the downstream target gene of Twist, which is in agreement with a previous report that activation of $\beta$-catenin pathway by Twist is critical for the maintenance of EMT associated CSC-like characteristics (64).

BrMC is a novel ChR analogue synthesized by our laboratory. We previously showed that the effect of BrMC on the inhibition of proliferation and induction of apoptosis in the colon cancer cell line HT-29, breast cancer and in the gastric cancer cell line SGC-7901 was stronger than that of $\mathrm{ChR}(37,65,66)$. BrMC has been shown to induce apoptosis of HCC cell line in a dose-dependent manner, but have little effect on human embryo liver L-02 cells. In addition, BrMC also inhibits self-renewal of glioma stem-like cells (GSLCs) $(39,40)$. In this study, we found that BrMC inhibited formation of primary and secondary spheroids in suspension and cell viability in those spheroids, inhibited self-renewal, EMT, cell invasion of $\mathrm{CD}_{133^{+}}$sphere-forming cells from SMMC-7721 cell line in vitro. Furthermore, BrMC suppressed tumorigenicity in BALB/c nu mouse xenograft model. As the molecular mechanism, BrMC dose-dependently inhibited the expression of CD133 and CD44, which was related to LCSC characteristics and also reduced protein levels of EMT-associated crucial protein Twist and $\beta$-catenin.

In conclusion, we present supportive evidence for the first time that BrMC, a novel synthetic chrysin analogue, was able to target LCSCs both in vitro and in vivo. Furthermore, our study identified the blockage of Twist signaling pathway by $\mathrm{BrMC}$ as one of the possible mechanisms for this efficacy. This study supports the use of BrMC for HCC chemoprevention or chemotherapy.

\section{Acknowledgements}

This study was supported in part by National Natural Science Foundation of China (General Program, no. 81172375), by program for excellent talents in Hunan Normal University (no. ET13107), by the Construct Program of the Key Discipline of Basic Medicine in Hunan Province and Research Fund for the Doctoral Program of Hunan Normal University (no. 110656).

\section{References}

1. el-Serag HB: Epidemiology of hepatocellular carcinoma. Clin Liver Dis 5: 87-107, 2001.

2. Stebbing J, Filipovic A and Giamas G: Claudin-1 as a promoter of EMT in hepatocellular carcinoma. Oncogene: doi:10.1038, 2013.

3. Wang F, He L, Dai WQ, et al: Salinomycin inhibits proliferation and induces apoptosis of human hepatocellular carcinoma cells in vitro and in vivo. PLoS One 7: e50638, 2012.

4. Wang Y, Liu YH, Jiang JS and Cui HB: A new method for purification and identification of hepatocellular carcinoma stem cell of SMMC-7721. Zhonghua Yi Xue Za Zhi 92: 3434-3437, 2012 (In Chinese).

5. Keung EZ, Nelson PJ and Conrad C: Concise review: genetically engineered stem cell therapy targeting angiogenesis and tumor stroma in gastrointestinal malignancy. Stem Cells 31: 227-235, 2012.

6. Vu NB, Nguyen TT, Tran LC, et al: Doxorubicin and 5-fluorouracil resistant hepatic cancer cells demonstrate stem-like properties. Cytotechnology 65: 491-503, 2012.

7. Song K, Wu J and Jiang C: Dysregulation of signaling pathways and putative biomarkers in liver cancer stem cells (Review). Oncol Rep 29: 3-12, 2013.

8. Lapidot T, Sirard C, Vormoor J, et al: A cell initiating human acute myeloid leukaemia after transplantation into SCID mice. Nature 367: 645-648, 1994.

9. Yin AH, Miraglia S, Zanjani ED, et al: AC133, a novel marker for human hematopoietic stem and progenitor cells. Blood 90: 5002-5012, 1997.

10. Miraglia S, Godfrey W, Yin AH, et al: A novel five-transmembrane hematopoietic stem cell antigen: isolation, characterization and molecular cloning. Blood 90: 5013-5021, 1997.

11. de Antonellis P, Liguori L, Falanga A, et al: MicroRNA 199b-5p delivery through stable nucleic acid lipid particles (SNALPs) in tumorigenic cell lines. Naunyn Schmiedebergs Arch Pharmacol 386: 287-302, 2013.

12. Ma S: Biology and clinical implications of CD133(+) liver cancer stem cells. Exp Cell Res 319: 126-132, 2013.

13. Chen Y, Yu D, Zhang H, et al: CD133(+)EpCAM(+) phenotype possesses more characteristics of tumor initiating cells in hepatocellular carcinoma Huh7 cells. Int J Biol Sci 8: 992-1004, 2012.

14. Nagano H, Ishii H, Marubashi S, et al: Novel therapeutic target for cancer stem cells in hepatocellular carcinoma. J Hepatobiliary Pancreat Sci 19: 600-605, 2012.

15. Pang RW and Poon RT: Cancer stem cell as a potential therapeutic target in hepatocellular carcinoma. Curr Cancer Drug Targets 12: 1081-1094, 2012.

16. Na DC, Lee JE, Yoo JE, Oh BK, Choi GH and Park YN: Invasion and EMT-associated genes are up-regulated in B viral hepatocellular carcinoma with high expression of CD133-human and cell culture study. Exp Mol Pathol 90: 66-73, 2011.

17. Thisse B, Stoetzel C, Gorostiza-Thisse $C$ and Perrin-Schmitt F: Sequence of the twist gene and nuclear localization of its protein in endomesodermal cells of early Drosophila embryos. EMBO J 7: 2175-2183, 1988.

18. Murre C, McCaw PS, Vaessin H, et al: Interactions between heterologous helix-loop-helix proteins generate complexes that bind specifically to a common DNA sequence. Cell 58: 537-544, 1989.

19. Jan YN and Jan LY: HLH proteins, fly neurogenesis and vertebrate myogenesis. Cell 75: 827-830, 1993.

20. Kadesch T: Consequences of heteromeric interactions among helix-loop-helix proteins. Cell Growth Differ 4: 49-55, 1993.

21. Yang J, Mani SA, Donaher JL, et al: Twist, a master regulator of morphogenesis, plays an essential role in tumor metastasis. Cell 117: 927-939, 2004.

22. Kwok WK, Ling MT, Lee TW, et al: Up-regulation of TWIST in prostate cancer and its implication as a therapeutic target. Cancer Res 65: 5153-5162, 2005.

23. Fu J, Qin L, He T, et al: The TWIST/Mi2/NuRD protein complex and its essential role in cancer metastasis. Cell Res 21: 275-289, 2011. 
24. Lee TK, Poon RT, Yuen AP, et al: Twist overexpression correlates with hepatocellular carcinoma metastasis through induction of epithelial-mesenchymal transition. Clin Cancer Res 12 : 5369-5376, 2006.

25. Devereux TR, Stern MC, Flake GP, et al: CTNNB1 mutations and beta-catenin protein accumulation in human hepatocellular carcinomas associated with high exposure to aflatoxin B1. Mol Carcinog 31: 68-73, 2001

26. Hsu HC, Jeng YM, Mao TL, Chu JS, Lai PL and Peng SY: Beta-catenin mutations are associated with a subset of low-stage hepatocellular carcinoma negative for hepatitis B virus and with favorable prognosis. Am J Pathol 157: 763-770, 2000.

27. Wong CM, Fan ST and Ng IO: beta-catenin mutation and overexpression in hepatocellular carcinoma: clinicopathologic and prognostic significance. Cancer 92: 136-145, 2001

28. Zhang T, Chen X, Qu L, Wu J, Cui R and Zhao Y: Chrysin and its phosphate ester inhibit cell proliferation and induce apoptosis in HeLa cells. Bioorg Med Chem 12: 6097-6105, 2004.

29. Woo KJ, Jeong YJ, Park JW and Kwon TK: Chrysin-induced apoptosis is mediated through caspase activation and Akt inactivation in U937 leukemia cells. Biochem Biophys Res Commun 325: 1215-1222, 2004

30. Lee SJ, Yoon JH and Song KS: Chrysin inhibited stem cell factor (SCF)/c-Kit complex-induced cell proliferation in human myeloid leukemia cells. Biochem Pharmacol 74: 215-225, 2007.

31. Ramos AM and Aller P: Quercetin decreases intracellular GSH content and potentiates the apoptotic action of the antileukemic drug arsenic trioxide in human leukemia cell lines. Biochem Pharmacol 75: 1912-1923, 2008

32. Wang W, VanAlstyne PC, Irons KA, Chen S, Stewart JW and Birt DF: Individual and interactive effects of apigenin analogs on $\mathrm{G} 2 / \mathrm{M}$ cell-cycle arrest in human colon carcinoma cell lines. Nutr Cancer 48: 106-114, 2004.

33. Zhang Q, Zhao XH and Wang ZJ: Flavones and flavonols exert cytotoxic effects on a human oesophageal adenocarcinoma cell line (OE33) by causing $\mathrm{G} 2 / \mathrm{M}$ arrest and inducing apoptosis. Food Chem Toxicol 46: 2042-2053, 2008

34. Kachadourian R, Leitner HM and Day BJ: Selected flavonoids potentiate the toxicity of cisplatin in human lung adenocarcinoma cells: a role for glutathione depletion. Int J Oncol 31: 161-168, 2007.

35. Walle T, Otake Y, Brubaker JA, Walle UK and Halushka PV: Disposition and metabolism of the flavonoid chrysin in normal volunteers. Br J Clin Pharmacol 51: 143-146, 2001

36. Park H, Dao TT and Kim HP: Synthesis and inhibition of PGE2 production of 6,8-disubstituted chrysin derivatives. Eur J Med Chem 40: 943-948, 2005.

37. Zheng X, Meng WD, Xu YY, Cao JG and Qing FL: Synthesis and anticancer effect of chrysin derivatives. Bioorg Med Chem Lett 13: 881-884, 2003

38. Ai XH, Zheng X, Tang XQ, et al: Induction of apoptosis of human gastric carcinoma SGC-7901 cell line by 5, 7-dihydroxy8-nitrochrysin in vitro. World J Gastroenterol 13: 3824-3828, 2007.

39. Yang XH, Zheng X, Cao JG, Xiang HL, Liu F and Lv Y: 8-Bromo-7-methoxychrysin-induced apoptosis of hepatocellular carcinoma cells involves ROS and JNK. World J Gastroenterol 16: 3385-3393, 2010

40. Feng X, Zhou Q, Liu C and Tao ML: Drug screening study using glioma stem-like cells. Mol Med Rep 6: 1117-1120, 2012.

41. Li Q, Gu X, Weng H, et al: Bone morphogenetic protein-9 (BMP-9) induces epithelial to mesenchymal transition (EMT) in hepatocellular carcinoma cells. Cancer Sci 104: 398-408, 2013.

42. Liu FY, Deng YL, Li Y, et al: Down-regulated KLF17 expression is associated with tumor invasion and poor prognosis in hepatocellular carcinoma. Med Oncol 30: 425, 2013.

43. Tanaka S, Shiraha H, Nakanishi Y, et al: Runt-related transcription factor 3 reverses epithelial-mesenchymal transition in hepatocellular carcinoma. Int J Cancer 131: 2537-2546, 2012.

44. El-Haibi CP, Bell GW, Zhang J, et al: Critical role for lysyl oxidase in mesenchymal stem cell-driven breast cancer malignancy. Proc Natl Acad Sci USA 109: 17460-17465, 2012.
45. Singh N, Liu G and Chakrabarty S: Isolation and characterization of calcium sensing receptor null cells: a highly malignant and drug resistant phenotype of colon cancer. Int J Cancer 132: 1996-2005, 2013

46. Yang MH, Chen CL, Chau GY, et al: Comprehensive analysis of the independent effect of twist and snail in promoting metastasis of hepatocellular carcinoma. Hepatology 50: 1464-1474, 2009.

47. Barr MP, Gray SG, Hoffmann AC, et al: Generation and characterisation of cisplatin-resistant non-small cell lung cancer cell lines displaying a stem-like signature. PLoS One 8: e54193, 2013.

48. Meng F, Glaser SS, Francis H, et al: Functional analysis of microRNAs in human hepatocellular cancer stem cells. J Cell Mol Med 16: 160-173, 2012.

49. Ji J and Wang XW: Clinical implications of cancer stem cell biology in hepatocellular carcinoma. Semin Oncol 39: 461-472, 2012.

50. Pardal R, Clarke MF and Morrison SJ: Applying the principles of stem-cell biology to cancer. Nat Rev Cancer 3: 895-902, 2003.

51. Marx J: Cancer research. Mutant stem cells may seed cancer Science 301: 1308-1310, 2003.

52. Swindall AF, Londono-Joshi AI, Schultz MJ, Fineberg N, Buchsbaum DJ and Bellis SL: ST6Gal-I protein expression is upregulated in human epithelial tumors and correlates with stem cell markers in normal tissues and colon cancer cell lines. Cancer Res 73: 2368-2378, 2013.

53. Lehnus KS, Donovan LK, Huang X, et al: CD133 glycosylation is enhanced by hypoxia in cultured glioma stem cells. Int J Oncol 42: 1011-1017, 2013

54. Zeng Z, Ren J, O'Neil M, et al: Impact of stem cell marker expression on recurrence of TACE-treated hepatocellular carcinoma post liver transplantation. BMC Cancer 12: 584, 2012.

55. Hori Y: Prominin-1 (CD133) reveals new faces of pancreatic progenitor cells and cancer stem cells: current knowledge and therapeutic rerspectives. Adv Exp Med Biol 777: 185-196, 2013.

56. Lee HH, Seo KJ, An CH, Kim JS and Jeon HM: CD133 expression is correlated with chemoresistance and early recurrence of gastric cancer. J Surg Oncol 106: 999-1004, 2012.

57. Yi H, Cho HJ, Cho SM, et al: Blockade of interleukin-6 receptor suppresses the proliferation of H460 lung cancer stem cells. Int J Oncol 41: 310-316, 2012.

58. Grosse-Gehling P, Fargeas CA, Dittfeld C, et al: CD133 as a biomarker for putative cancer stem cells in solid tumours: limitations, problems and challenges. J Pathol 229: 355-378, 2013.

59. Yin $\mathrm{S}, \mathrm{Li} \mathrm{J}, \mathrm{Hu} \mathrm{C}$, et al: CD133 positive hepatocellular carcinoma cells possess high capacity for tumorigenicity. Int J Cancer 120: 1444-1450, 2007

60. De Hert M, Dockx L, Bernagie C, et al: Prevalence and severity of antipsychotic related constipation in patients with schizophrenia: a retrospective descriptive study. BMC Gastroenterol 11: 17,2011

61. Qu F, Zhai W, Chen H, Zhu LH and Morris TJ: Cloning, characterization and transient expression of the gene encoding a rice $\mathrm{U} 3$ small nuclear RNA. Gene 172: 217-220, 1996.

62. Wu Y, Ginther C, Kim J, et al: Expression of Wnt3 activates Wnt/ $\beta$-catenin pathway and promotes EMT-like phenotype in trastuzumab-resistant HER2-overexpressing breast cancer cells. Mol Cancer Res 10: 1597-1606, 2012.

63. Grosse-Steffen T, Giese T, Giese N, et al: Epithelial-tomesenchymal transition in pancreatic ductal adenocarcinoma and pancreatic tumor cell lines: the role of neutrophils and neutrophil-derived elastase. Clin Dev Immunol 2012: 720768 , 2012.

64. Li J and Zhou BP: Activation of beta-catenin and Akt pathways by Twist are critical for the maintenance of EMT associated cancer stem cell-like characters. BMC Cancer 11: 49, 2011.

65. Xiang HL, Zheng $X$ and Cao JG: Induction of apoptosis of human gastric carcinoma SGC-790 cell line by 8-bromo-7mehoxychrysin. Zhongguo Yaolixue Tongbao 24: 1370-1372, 2008.

66. Zhao XC, Tian L, Cao JG and Liu F: Induction of apoptosis by 5,7-dihydroxy-8-nitrochrysin in breast cancer cells: the role of reactive oxygen species and Akt. Int J Oncol 37: 1345-1352, 2010. 